\title{
The moribund mango tree
}

$\mathrm{T}$

hroughout our childhood, my sister and I spent the hot summers of India in grandfather's village. Grandfather, in his crisp white shirt and trousers, greeted us at the railway station, always arriving at least a half-hour early. "Guess what your grandmother has cooked for you today," he would say as we got into the car. There was always a treat to be had at home, usually bhinda (okra) for my sister and mag (lentils) for me.

Grandfather's primary occupation was farming sugar cane and mangoes - but he was also known for his sharp mind and temper. He was a domineering presence, and we dared not do anything to displease him. His fierce temperament was matched only by his intense devotion toward us. As children, we knew his immaculate writing desk was off-limits, but it was okay to sit on his lap and enthusiastically steer the wheel as we "drove" his car. On nights when the power was out, we huddled with grandfather on his favourite swing while he sang us lullabies.

My grandparents lived in a kachcha (raw or unfinished) house. The floor was covered in coat after coat of dried (and remarkably scent-free) cow dung, yet the house offered modern amenities. Across from the house was a glorious mango tree, thick of trunk and heavy with alphonso fruit in the summers. My sister and I would eat the raw, tangy and sweet totapuris, sprinkled with salt and red pepper. Grandmother would caution us not to eat too many — we never listened — and soon our throats would be hoarse and our tongues raw. The alphonsos were carefully picked and packaged in cane baskets, then covered with jute cloth, ready for dispatch. Grandfather would assign us the task of marking these bags in green ink. "Make sure you write with your best handwriting," never one to accept anything but the best. He taught us how to tell one type of mango from another by

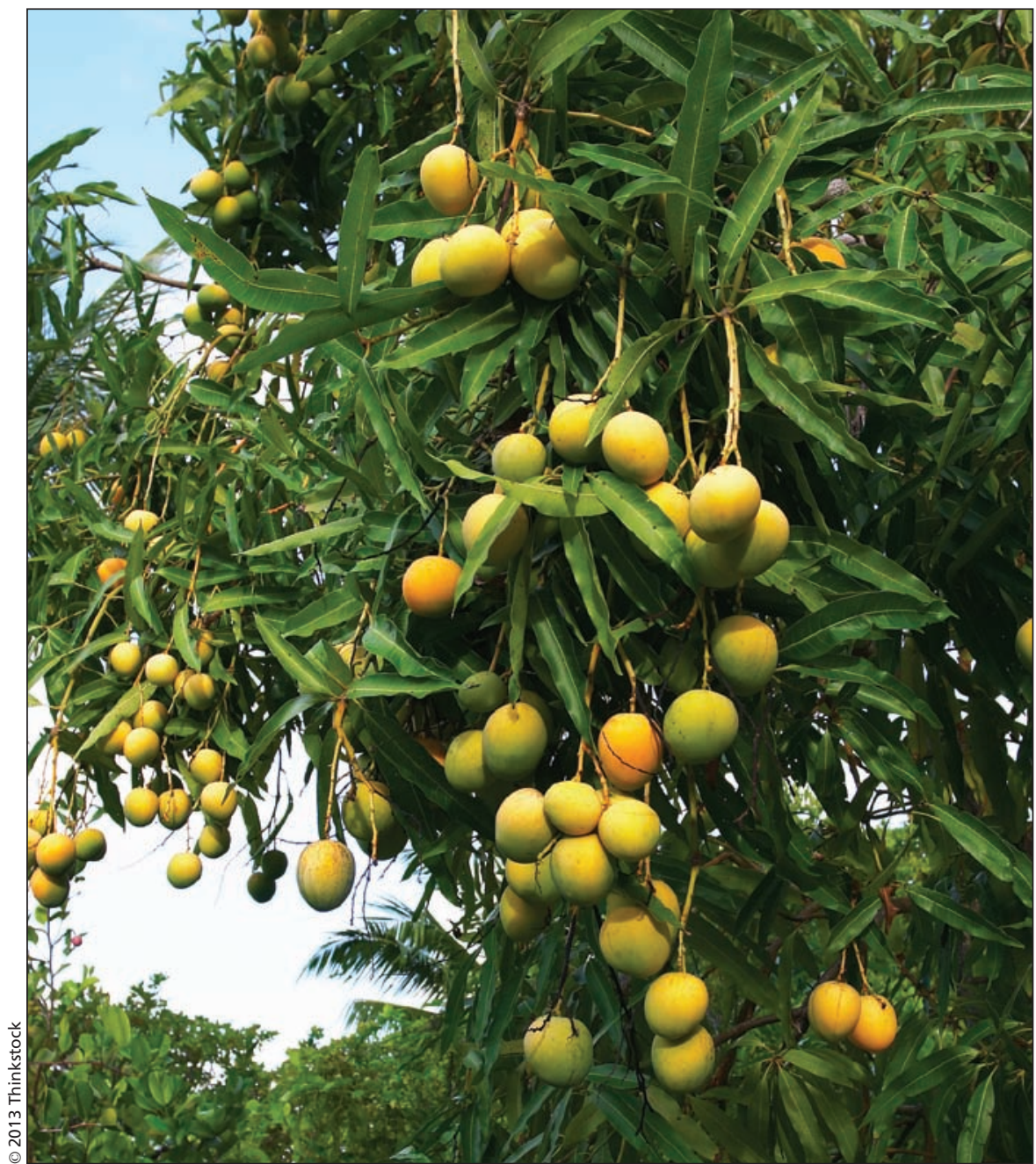

smell, the flavourful aaphus from the heady kesar; one best for eating, the other to be savoured as thick, smoothened pulp. The task of picking, pickling and eating mangoes loomed large on the summer itinerary and by the time the monsoons arrived, we had eaten more mangoes than could be deemed necessary or healthful.

As we grew older, our summer trips to the village became shorter, but the sweet mangoes from the village kept coming. When my sister left home for college, the mangoes arrived promptly at her hostel, much to the pleasure of her roommates. Some mangoes even attempted to make their way "across the seven seas" when I left for the USA, but much to my disappointment, their journey was cut short by Customs, the prospects for the tropical fruit dismal when pitted against international security.

On one later trip to the village, I noticed that the lush mango tree across from the house had been axed. "It was dying," grandfather said. For a short while, I was disappointed, but soon this loss was forgotten in my adolescent mind.

Eventually, the old house was sold, 
and my grandparents moved to the city. Our trips became shorter, and grandfather was never content with the amount of time we spent with him. "Stay tonight, you can take the early morning train tomorrow," he would posit. "What difference will a few hours make, Papa? Plus, I will have to wake up so early in the morning!" I would counter. In the end, he would win. I resented his uncompromising temperament and challenged it with my own, often leading to long and loud arguments that would leave us both emotionally exhausted.

In 2002, grandfather was diagnosed with advanced prostate cancer at the age of 70. Accustomed to a life of hardship, he did not disclose his symptoms to us until they were far advanced. His surgery went well, and he started hormonal ther- apy, to which he responded well. But he was a terribly noncompliant patient and stubborn in his ways as usual.

Then, last year, after a decade of good health, he started complaining of odd symptoms - he did not have an appetite, his back hurt, his bowels were hard. When I visited him in December, I was overcome by emotion when I saw him — frail and helpless - a mere wisp of the man I remembered. Though weak in body, his spirit was strong as ever. His daily routine hadn't changed either; he still oiled his head in the morning, shaved, took a sponge bath with eau-decologne, and then donned his white shirt and lungi. He would ask me: "Isn't there anything that can be done?"

When the news of his passing came, I was relieved that his suffering had finally come to a close. My thoughts went back to the dying mango tree and how, like the tree, grandfather too had withered away.

This summer, as I set out to purchase Mexican mangoes in the US, trying to sniff out the good ones from the bad, I thought of the mangoes of yore, and remembered grandfather and the bountiful mangoes of our village orchard. When my husband remarked at dinner that the mangoes this year were sweet, to me, their flavour was only bittersweet.

\section{Krishna Acharya MBBS MPH}

Arkansas Children's Hospital

Little Rock, Arkansas

Author's note: Alphonso, also aaphus, kesar, totapuri are varieties of Indian mangoes; lungi is a long, cotton loincloth worn around the waist). This is a true story.

CMAJ 2013. DOI:10.1503/cmaj.121371 